\title{
A differential interplay between the expression of Th1/Th2/Treg related cytokine genes in Teladorsagia circumcincta infected DRB1*1101 carrier lambs
}

Musa Hassan ${ }^{1,2}$, James P Hanrahan², Barbara Good², Grace Mulcahy' ${ }^{1}$ Torres Sweeney ${ }^{1 *}$

\begin{abstract}
Substantial debate exists on whether the immune response between sheep resistant and susceptible to gastrointestinal nematodes can be differentiated into a Th1 and Th2 phenotype. The present study addresses the hypothesis that variation in resistance to Teladorsagia circumcincta between DRB1*1101 (associated with reduced faecal egg count and worm burden) carriers and non-carriers is due to a differential interplay in the expression of Th1/Th2 and regulatory $T$ (Treg) related cytokine genes. Lambs from each genotype were either slaughtered at day 0 (un-infected control) or infected with $3 \times 10^{4}$ Teladorsagia circumcincta L3 and slaughtered at 3, 7, 21, and 35 days later. Lambs carrying the DRB1*1101 allele had a significantly lower worm burden $(P<0.05)$ compared to the non-carriers. Abomasal mucosal cytokine gene expression was evaluated by quantitative real-time PCR and comparison made for time and genotype effects. The response generated varied through the course of infection and was affected by genotype. DRB ${ }^{*} 1101$ carriers had an up-regulated expression of the Th1-related cytokine genes (IL-1 $\beta, T N F \alpha$, and IFN- $\gamma$ ) at day 3, but this was replaced by an up-regulated expression of Th2-related cytokine genes (IL-10 and IL-13) and Treg-related cytokine genes (IL-2RA-CD25, TGF $\alpha$, TGF $\beta$, Arg2, MIF and FOXP3) by day 7 . Conversely, in the non-carriers these changes in gene expression were delayed until days 7 and 21 post infection (pi), respectively. It is concluded that resistance to Teladorsagia circumcincta in animals carrying the $D R B 1^{*} 1101$ allele is influenced by an earlier interplay between Th1, Th2 and T regulatory immune response genes.
\end{abstract}

\section{Introduction}

The abomasal parasite, Teladorsagia circumcincta (T. circumcincta) is a major impediment to sheep production in temperate and subtropical climates [1] both in terms of animal welfare and economic loss $[2,3]$. While anthelmintics can be used to control gastrointestinal nematodes, the increased incidence of drug resistance [4-6] and demands for meat products free of chemical residues [7] have led to greater interest in alternative parasite control strategies.

While both cellular and humoral immune responses contribute to protective immunity against gastrointestinal nematodes, the dichotomy of protective immunity

\footnotetext{
* Correspondence: torres.sweeney@ucd.ie

'School of Agriculture, Food Science, and Veterinary Medicine, University College Dublin, Dublin 4, Dublin, Ireland

Full list of author information is available at the end of the article
}

against gastrointestinal nematodes remains unclear in sheep. Susceptibility or resistance to gastrointestinal nematodes in sheep has often been attributed to a CD4 ${ }^{+}$ T-helper type 1 (Th1) or CD4 $4^{+}$T-helper type 2 (Th2) immune responses. Indeed depletion of $\mathrm{CD}^{+} \mathrm{T}$ helper cells abrogated resistance to Haemonchus contortus (H. contortus) [8]. Similarly, expression of Th2 related cytokines was observed in mesenteric lymph [9], abomasal lymph nodes [10-12], abomasal mucosa [13], and blood [14] of sheep infected with gastrointestinal nematodes. However, there is evidence for the concurrent expression of Th1 and Th2 genes $[9,15]$ and more recent evidence for the involvement of immunoregulatory genes $[12,13,16]$ in animals undergoing nematode challenge. This evidence puts into question the existence of a clear Th1/Th2 dichotomy. Additionally, immune regulatory cells such as fork-head box-P3 ${ }^{+}\left(\mathrm{FOXP}^{+}\right)$
C Biomed Central

(c) 2011 Hassan et al; licensee BioMed Central Ltd. This is an Open Access article distributed under the terms of the Creative Commons Attribution License (http://creativecommons.org/licenses/by/2.0), which permits unrestricted use, distribution, and reproduction in any medium, provided the original work is properly cited. 
[17] and CD25 $5^{+} \mathrm{T}$ lymphocytes [18] have been observed in sheep undergoing T. circumcincta infection. Therefore, susceptibility to $T$. circumcincta may not be due to a Th1/Th2 balance but rather a failure of immunoregulatory (Treg) responses that terminate inappropriate inflammatory responses, whether Th1 or Th2, while allowing the development of essential immune responses.

In the current study a group of $D R B 1 \% 1101$ carrier and non-carrier lambs, experimentally infected with $T$. circumincta was used in a time-course mucosal gene expression assay to characterise the chronological changes in Th1-, Th2- and Treg-related cytokine gene expression. It has previously been shown that lambs carrying the Ovar-DRB1*1101 allele are more resistant to T. cirumcincta than non-carriers of this allele, as measured by worm burden [19].

\section{Materials and methods}

\section{Animals and experimental design}

Six unrelated sires heterozygous for the DRB1*1101 allele were mated with ewes in single sire groups to generate progeny carrying or lacking the $D R B 1 * 1101$ allele. This allele was initially named G2 [20,21] and $D R B 1 * 0203$ [22]. However due to the international standardisation of the nomenclature of the MHC alleles, this allele is now known as the DRB1*1101 [23]. All lambs were genotyped at the Ovar-DRB1 locus, by short tandem repeat (STR) analysis and confirmed by direct sequencing of genomic DNA, as previously described $[22,24]$. It was intended that lambs used in the study would be twin pairs where one sibling was a carrier of the $D R B 1 * 1101$ allele and the other sibling a non-carrier. Within the constraints of birth date, birth type and lamb survival, 18 suitable twin pairs were identified. These were randomly assigned to one of five slaughter dates (days $0,3,7,21$, and 35 of the experiment) subject to the constraints that there were a maximum of four pairs per slaughter date. To maintain numerical balance in the design, we utilised a twin pair where both siblings were carriers on day 3 and another pair where both siblings were non carriers on day 21. The lambs were born indoors at the Teagasc Animal Production Research Centre, and were put to pasture until they were between 4 and 5 weeks of age when they were moved back indoors with their dams. All lambs were weaned 1 week later and faecal sampled to determine faecal egg count 3 weeks after weaning $(80 \%$ of the lambs had a FEC < 150 and the maximum FEC observed was 250) and treated with Oramec (Merial Animal Health Ltd, Essex, UK) as per the manufacturer's instructions. The lambs were moved to Lyons Research Farm, University College Dublin, at about 10 weeks of age, housed in a nematode free environment and given 2 weeks to acclimatise prior to the start of the experiment. The lambs were free of nematode infection at the start of the experiment, based on FEC measurements on three consecutive days. All procedures described in this experiment were conducted under experimental licence from the Irish Department of Health in accordance with the Cruelty to Animals Act 1876 and the European Communities (Amendments of the Cruelty to Animals Act, 1976) Regulations, 1994. The lambs received granulated feed and water ad libitum. At about 12 weeks of age, eight lambs were slaughtered (day 0; controls) and the remaining lambs each received a single oral dose of $3 \times 10^{4} \mathrm{~T}$. circumcincta L3. The subsequent slaughter dates were chosen based on the developmental stages of the parasite in the sheep abomasum; day 3 (L3 stage), day 7 (L4 stage) and days 21 and 35 (egg laying stage).

\section{Tissue collection}

The abomasum was removed at slaughter and rinsed in saline. The abomasal mucosa was then removed by scraping with a blunt blade. The abomasal scrapings from these lambs and the unchallenged lambs were preserved in RNAlater ${ }^{\circledR}$ (Applied Biosystems, Warrington, $\mathrm{UK})$ and stored at $-20^{\circ} \mathrm{C}$ until use.

\section{RNA extraction}

RNA was extracted from the stored abomasal scrapings using TRI Reagent ${ }^{\circledR}$ (Bio-Sciences Ltd, Dublin, Ireland) as per the manufacturer's recommendations. Samples were homogenised in $1 \mathrm{~mL}$ TRI Reagent ${ }^{\circledR}$ using a Retsch $^{\circledR}$ tissuelyser (Qiagen, Crawley, UK) and $0.2 \mathrm{~mL}$ chloroform (Sigma Aldrich, Wicklow, Ireland) added for phase separation. The aqueous phase was transferred to a fresh eppendorf tube (Eppendorf, Hamburg, Germany) and mixed with $0.5 \mathrm{~mL}$ isopropanol. This was then centrifuged at $10000 \times g$ for $15 \mathrm{~min}$ at $4^{\circ} \mathrm{C}$ to collect the RNA pellet. The pellet was then washed in $75 \%$ ethanol and dissolved in RNAse free water.

RNA clean-up was performed using the RNeasy ${ }^{\circledR}$ mini kit (Qiagen) as per the manufacturers' recommendations. RNA was quantified by spectrophotometric measurements at $260 \mathrm{~nm}$ and purity was assessed by determining the OD ratio $260 / 280 \mathrm{~nm}$. RNA integrity was assessed using Agilent ${ }^{\circledR} 2100$ bionalyzer (Agilent Technologies, Cork, Ireland). Only samples with RNA integrity number (RIN) above eight were used in the gene expression assay.

\section{Reverse transcription of mRNA into CDNA}

Total RNA was transcribed into cDNA using RevertAid $^{\mathrm{TM}} \mathrm{H}$ minus First strand cDNA synthesis kit (Fermentas, St. Leon-Rot, Germany) and oligo $(\mathrm{dT})_{18}$. Each $40 \mu \mathrm{L}$ reaction was set up on ice and consisted of $2 \mu \mathrm{g}$ RNA, $1 \mu \mathrm{g}$ oligo $(\mathrm{dT})_{18}$ primer, $1 \mathrm{X}$ reaction buffer, 20 
units Ribolock ${ }^{\mathrm{TM}}$ Ribonuclease inhibitor, $1 \mathrm{mM}$ dNTP mix, 400 units RevertAid ${ }^{\mathrm{TM}} \mathrm{H}$ minus M-MuLV RT and made up to $40 \mu \mathrm{L}$ using DEPC treated water. Subsequent to incubation at $42^{\circ} \mathrm{C}$ for $1 \mathrm{~h}$, the enzyme was deactivated at $70^{\circ} \mathrm{C}$ for $5 \mathrm{~min}$ and the cDNA chilled on ice. The cDNA was then made up to $200 \mu \mathrm{L}$ using RNAse free water and stored at $-20^{\circ} \mathrm{C}$. A 1:2 serial dilution made from a pool of all the cDNA samples was also stored at $-20^{\circ} \mathrm{C}$.

\section{Quantitative Real-Time PCR assay}

Quantitative real time PCR (qPCR) was used to determine transcript abundances for the 19 genes and 5 reference genes described in Table 1. To minimise potential variations, samples from all the time points were set up on the same plate for each gene. Further, the efficiency of the qPCR was determined for each gene [25]. qPCR was performed on ABI Prism 7500 Fast sequence detection system (Applied Biosystems). Each $20 \mu \mathrm{L}$ reaction contained $1 \times$ Fast SYBR green Master Mix (Applied Biosystems), $5 \mathrm{mM}$ of each primer and a constant amount of cDNA, corresponding to $10 \mathrm{ng}$ of transcribed RNA for each sample. For each gene, an aliquot of the pooled cDNA sample was set up along with the test samples and used to calculate the PCR efficiency [25].

The oligonucleotide primers used to assay these genes have been previously published $[12,13,26]$. To normalise the expression data, a normalisation factor was derived from the five reference genes using Genorm ${ }^{\circledR}$ [27]; a combination of the ATPase and RPLP0 genes provided the best normalisation factor.

\section{Data analysis}

The normalisation factor was used to determine relative gene expression values at each time point [25]. A $t$-test was then used to evaluate the difference between the genetic groups at each time point post infection (pi) at $5 \%$ level of significance.

\section{Results}

\section{Worm numbers}

Detailed parasitology data obtained post-mortem from the abomasum contents and digest are presented in [19]. Significantly $(P<0.05)$ lower numbers of $T$. circumcincta were recovered from the abomasum of $D R B 1 * 1101$ carriers on days 21 and 35 (day 3 geometric mean, 8 919; day 7 geometric mean, 15 383, day 21 geometric mean, 12 654, day 35 geometric mean 2 228) compared to the non-carriers (day 3 geometric mean 7 149; day 7 geometric mean 19 062, day 21 geometric mean 20 836, day 35 geometric mean 8 333).

\section{Relative cytokine expression}

The expression levels of the Th1-related cytokine genes (IFN $\gamma$, TNF $\alpha$, IL-1 $\beta$, and IL-12) are presented in Figure 1. Following infection, a significant up-regulation of IFN $\gamma$, TNF $\alpha$ and IL- $1 \beta$ was observed on day $3(P<0.05)$ in the $D R B 1 * 1101$ carriers compared to the non-carriers, followed with significant down-regulation by day 7. Up-regulation of IL- $1 \beta$, IFN $\gamma$ and TNF $\alpha$ was not observed in the noncarriers until day 7 pi followed by a significant downregulation by day 21 .

The expression pattern of IL-12 was different to the other Th1 cytokines examined. IL-12 expression was up-regulated by day 3 in all genotypes and remained elevated for the duration of the experiment. The noncarrier lambs had significantly $(P<0.05)$ higher level of IL-12 than the carrier lambs.

The expression levels of the Th2-associated cytokine genes (IL-4, IL-10, and IL-13) are presented in Figure 2. There was a significant up-regulation of IL-10 and IL-13 by day 7 in the carrier lambs and by day 21 in the noncarrier lambs. The up-regulation of these cytokines was followed by a significant down-regulation by day 35 in both groups. On the other hand, there was a significant up-regulation of IL-4 from day 7 followed by a downregulation on day 35 in both groups.

The expression levels of immunoregulatory-related genes (TGF $\alpha$, TGF $\beta$, IL-2RA-CD25, FOXP3, Arg2, and MIF) are presented in Figure 3. Significant $(P<0.05)$ increases in all the immunoregulatory cytokine genes assayed were observed on day 7 in the carriers compared to the non-carriers. However, the transcript levels for TGF $\beta$, IL-2RA/CD25, FOXP3, Arg2, and MIF increased significantly $(P<0.05)$ on day 21 in the noncarriers to reach levels similar to those observed in the carrier lambs on the same day.

\section{Extracellular matrix and mucosal integrity genes}

The expression of mucosal integrity genes are presented in Figure 4. Before infection, the non-carriers had significantly $(P<0.05)$ elevated levels of ITLN-2, TFF2, and

Table $1 \mathrm{~A}$ list of genes quantified by qPCR in the abomasal mucosa of DRB1*1101 carrier and non-carrier lambs following infection with $3 \times 10^{4} \mathrm{~T}$. circumcincta L3

\begin{tabular}{ll}
\hline Functional grouping & Gene names \\
\hline Cytokine-cytokine receptor signalling & Th1 (IL1 $\beta$, IL12, IFN $\gamma$, TNF $\alpha$, \\
Extracellular matrix & Th2 (IL4, IL10, IL13) immunoregulatory (IL2RA-D25, FOXP3, Arg2, MIF, TGF $\alpha$, TGF $\beta)$ \\
Reference genes & TFF2, TFF3, Ovar-Gal14, sITLN2, sMCP-1, GATA-3 \\
\hline
\end{tabular}



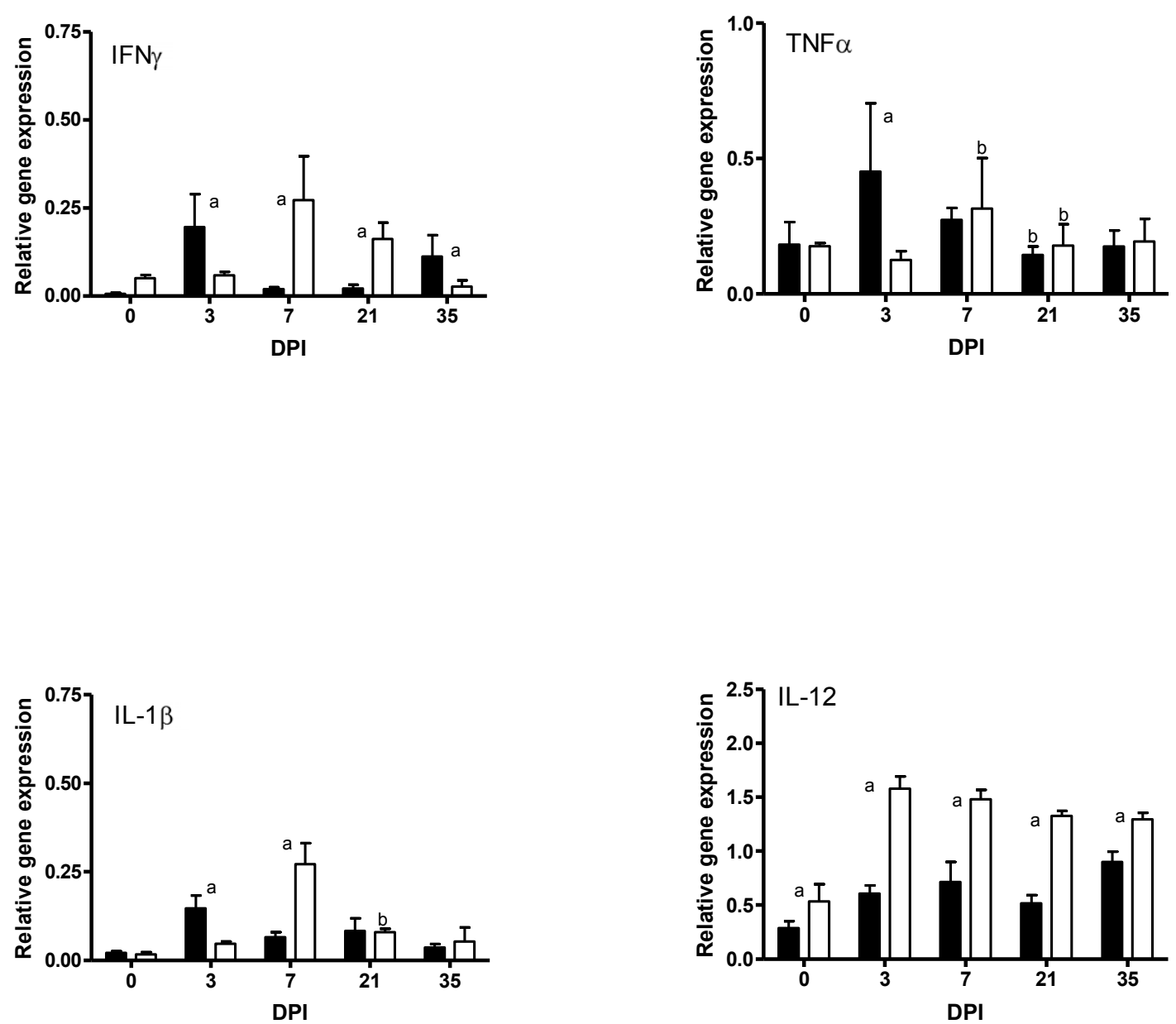

Figure 1 Relative expression of Th1 cytokines in the abomasal mucosa of $D R B 1 * 1101$ carrier (black bars) and non-carrier (white bars) lambs following infection with $3 \times 10^{4} \mathrm{~T}$. circumcincta $\mathrm{L} 3$. ( $\mathrm{a}=$ significant differences between genetic groups; $\mathrm{b}=$ significant differences with the preceding time point).

Ovar-Gal14 compared to the carriers. Following infection, the carrier lambs had significantly $(P<0.05)$ higher levels of ITNL2 on day 3 and GATA3 on day 7 compared to the non-carriers. The expression of TFF2 and Ovar-Gal14 was elevated until day 7 and was then down regulated on day 21 in both genetic groups. In contrast, there was an increased expression of TFF3, and SMCP-1 from day 21 in both groups.

\section{Discussion}

The outcome of infection is dependent on the balance between both the host survival and parasite virulence strategies $[28,29]$. In experimental nematode infections, susceptibility is thought to be associated with a Th1 immune response [12]. However, a prolonged inflammatory response would not be desirable to the host. On the other hand, resistant animals elicit a strong Th2 response, which is potentially hostile to the fitness strategy of nematodes [13]. Thus, the parasite may attempt to constrain or modulate the Th2 response in order to survive. It is not known if the parasites deregulate the Th2 response by down-regulating specific cytokines and inducing development of regulatory $\mathrm{T}$ cells, or if they down-regulate the Th2 response in favour of a Th1 response. In the present study, there was a rapid shift from a Th1 immune response characterised by the expression of IFN $\gamma$ and IL- $1 \beta$ genes to a regulated Th2 immune response characterised by the expression of IL-13, IL-10, TGF $\beta$, and FOXP3 genes by seven days post infection (dpi) in the carrier lambs. However, in the non-carrier lambs, the switch from the predominantly Th1 immune response was delayed until $21 \mathrm{dpi}$. Interestingly, the timing of the Th1/Th2/Treg immune switch coincided with the decline in worm burden in both group of lambs.

Increased expression of IL-10 and IL-13 was observed on day 7 in the $D R B 1 * 1101$ carriers. Conversely, the upregulation of these cytokines was delayed until day 21 in 

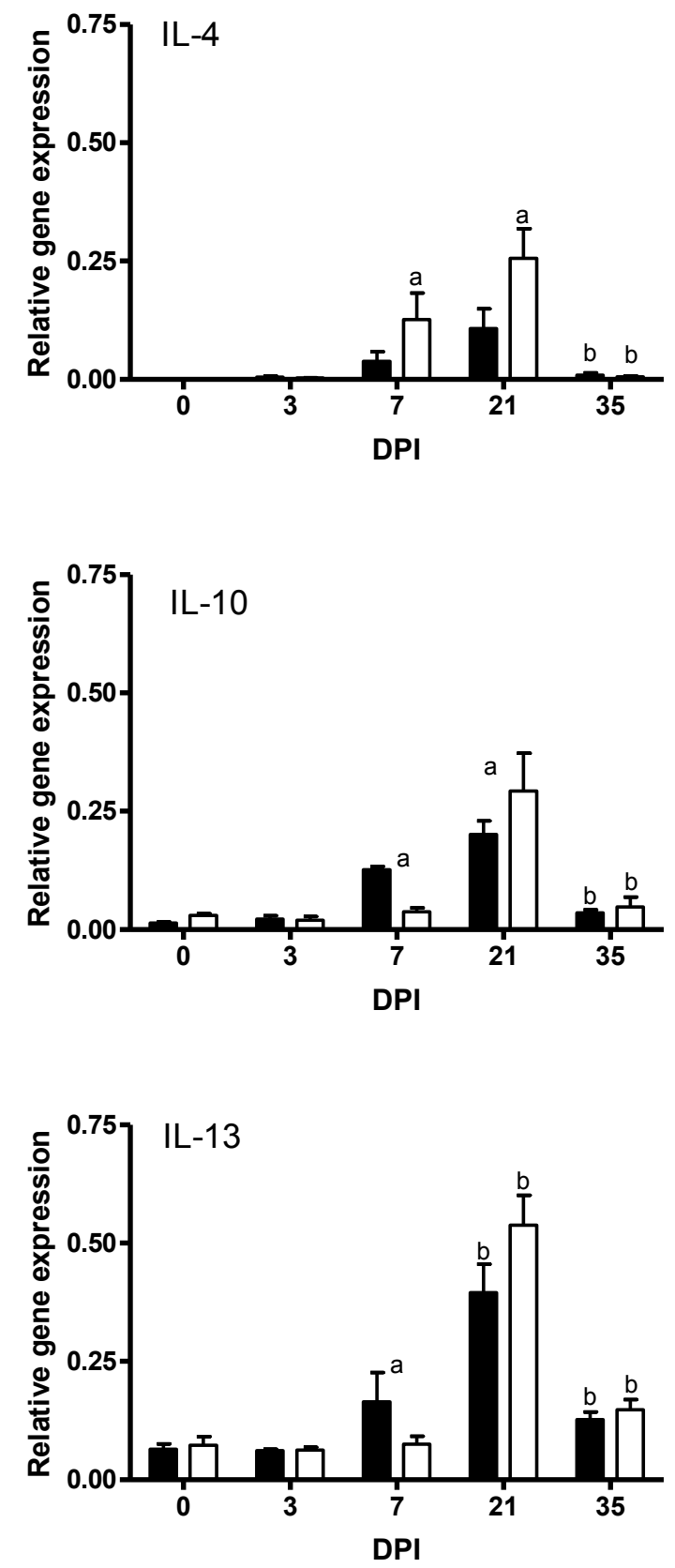

Figure 2 Relative expression of Th2 related cytokine genes in the abomasal mucosa of $D R B 1 * 1101$ carrier (black bars) and non-carrier (white bars) lambs following infection with $3 \times 10^{4}$ T. circumcincta L3. (a = significant differences between genetic groups; $b=$ significant differences with the preceding time point).

the non-carriers. Similar anti-inflammatory responses have been observed in sheep infected with $H$. contortus [11,30], T. colubriformis [31] and T. circumcincta [12], and in cattle infected with Ostertagia ostertagi [32]. IL13 is known to induce Th2 cell responses and promote the production of IgE [33]. IgE has been associated with increased resistance to $T$. circumcincta $[34,35]$ and the
IgE levels were up-regulated in the mucosa of these lambs on day 7 pi [19].

The up-regulation of TGF $\beta$, IL-2RA-CD25, FOXP3, Arg-2 and MIF on day 7 in the carrier lambs in the present study may reflect the role of these genes in immune regulation. Previously, $\mathrm{FOXP}^{+} \mathrm{T}$ cells [17], CD25 ${ }^{+} \mathrm{T}$ cells [18] and an up-regulation of IL-10 and TGF $\beta$ genes [12] have been observed in of sheep infected with $T$. circumcincta. Treg cells play a significant role in suppressing excessive immune response that may be deleterious to the host [36,37]. The cost of mounting an effective immune response against gastrointestinal nematodes has been extensively reviewed [38-40]. It is therefore argued, that in the interest of the host, the immune response be attenuated as soon as it has achieved its objective to enable the diversion of nutrients to other cellular functions, including growth. The interleukin-2 receptor alpha (IL-2RA) and FOXP3 are key regulatory genes for the development and function of cells with immunoregulatory functions [41]. Different types of Treg cells in humans and mice including $\mathrm{CD}^{+}$have been shown to express high levels of IL-2RA and such cells are a major proportion of the population of Treg cells [36]. IL-2RA/CD $25^{+}$knock-out mice have been shown to develop autoimmune disease [42], suggesting that this gene is needed for immune regulation. Arg-2 and MIF are considered markers of alternatively activated macrophages, markers of immune regulation $[43,44]$. Arg-2 is known to abrogate nitric oxide (NO) production, resulting in the inhibition of IFN $\gamma$-mediated apoptosis [45] a feature of susceptibility to gastrointestinal nematodes [16]. On the other hand, MIF is a critical mediator in innate and acquired immunity, exhibiting inflammatory functions [46] and anti-apoptotic activity [47]. MIF is produced by alternatively activated macrophages [48] and sustains macrophage survival and function by suppressing activation-induced apoptosis [49]. MIF is also known to influence IL-5-dependent tissue eosinphilia induced by Schistosoma mansoni infection in mice [50], and also plays a role in the control of worm fecundity in mice infected with Schistosoma japonicum [51]. It is interesting in this context that the expression of these molecules preceded a reduction in worm numbers in the carrier lambs. Nematodes have been reported to produce mouse homologues of this protein, and perhaps use it to modulate the host immune response, by inducing of alternative activation of host's macrophages [52]. The common denominator in these two molecules is their anti-apoptotic activity and immune regulation, processes associated with resistance to gastrointestinal nematodes $[53,54]$. The increased expression of antiapoptotic proteins, such as heat shock protein 70 , and B-cell leukaemia/lymphoma 2 (Bcl2), in carrier lambs at the same time point while the non-carriers had 

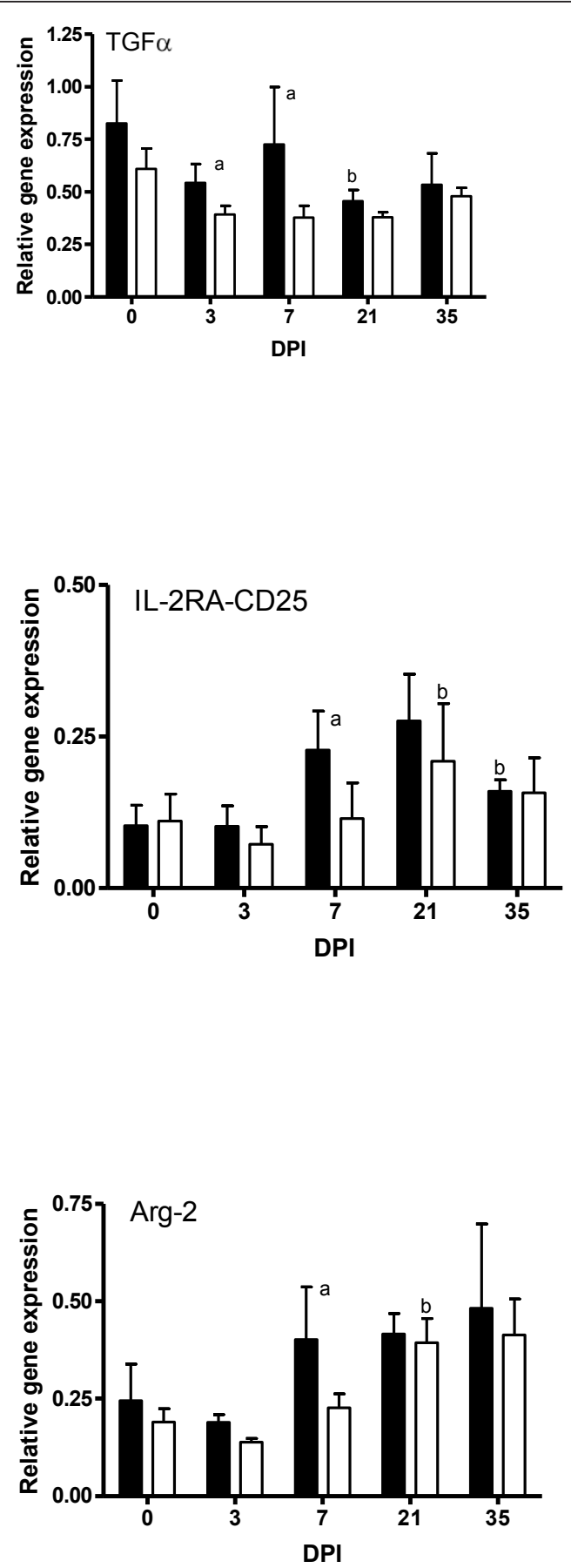

Figure 3 Relative expression of immunoregulatory related cytokine genes in the $D R B 1 * 1101$ carrier (black bars) and non-carrier (white bars) lambs following infection with $3 \times 10^{4} \mathrm{~T}$. circumcinta $\mathbf{L} 3$. ( $a=$ significant differences between genetic groups; $b=$ significant differences with the preceding time point).

increased expression of apoptosis related peroxiredoxin2 (Hassan et al., The proteome of the abomasal mucosa of lambs infected with Teladorsagia circumcincta - an important role for apoptosis? Prepared Manuscript) indicates that the expression of immunoregulatory genes is not only important in suppressing excessive immune
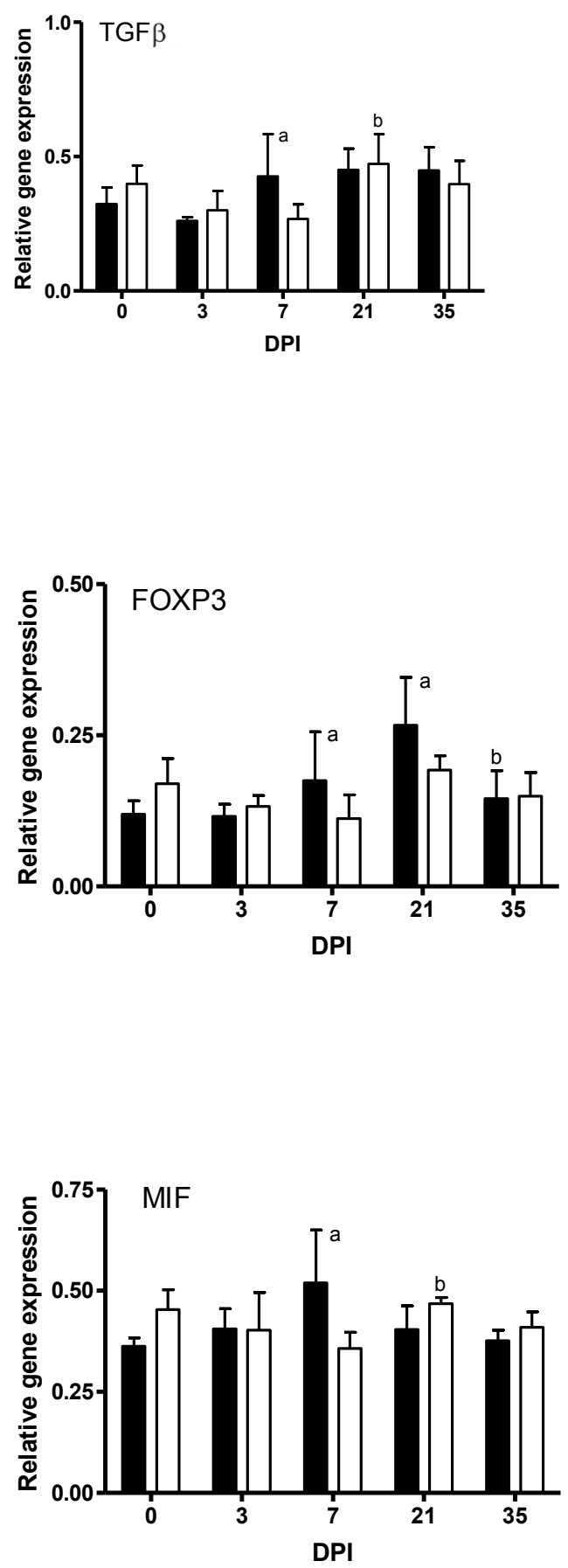

response, but also in regulating cell survival and viability.

The significant up-regulation of trefoil factor 3 (TFF3) in both genetic groups by day 21 pi is consistent with the suggestion that the viscosity of luminal contents may contribute to nematode localisation [13]. TFFs are 

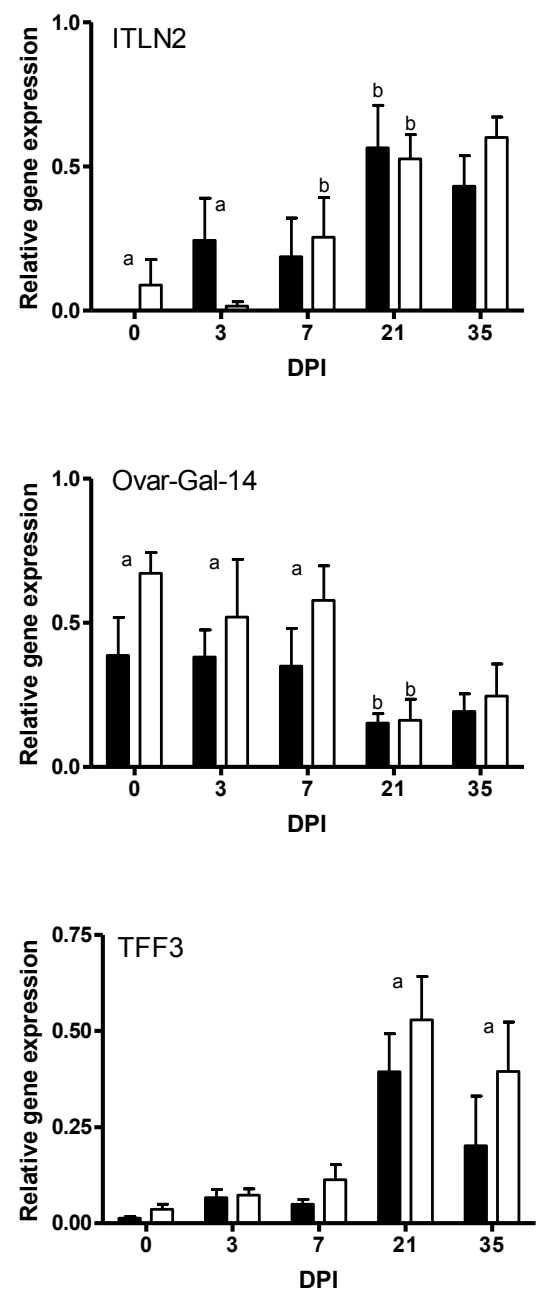
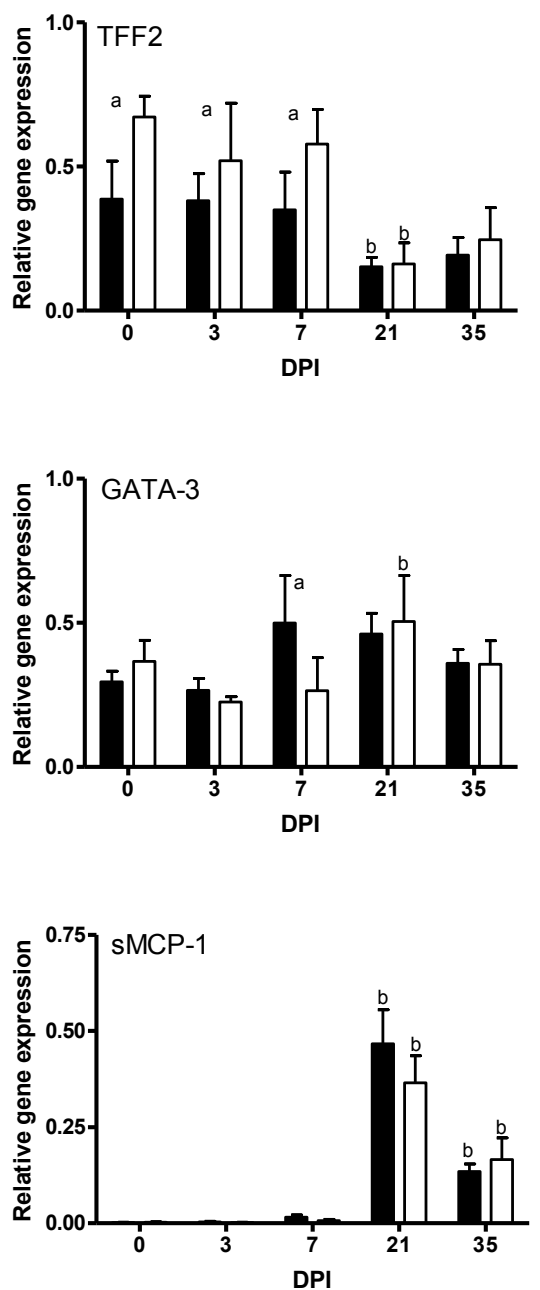

Figure 4 Relative expression of extracellular and mucosal integrity genes in the DRB1*1101 carrier (black bars) and non-carrier (white bars) lambs following infection with $3 \times 10^{4} \mathrm{~T}$. circumcinta $\mathrm{L} 3$. ( $\mathrm{a}=$ significant differences between genetic groups; $\mathrm{b}=$ significant differences with the preceding time point).

thought to be important in protecting the mucosa from insults [55-58] and the production of TFF3 is up-regulated by IL-4 and IL-13 [59]. It is therefore, feasible that the observed up-regulation of TFF3 is a response to IL4 and IL-13 production or mucosal damage following infection. The current study shows an up regulation of sheep interlectin-2 (sITLN-2) from day 3 in carrier lambs and from day 7 in the non-carriers relative to their corresponding day 0 controls. An up-regulation of sITLN-2 has been observed on day 10 in naive and day 3 in previously infected sheep following $T$. circumcincta challenge [26]. Interlectins are thought to play a role in altering the characteristics of mucus leading to parasite entrapment [60].

The increased expression of SMCP-1, a marker of mucosal mast cells [61,62], from day 21 in both genetic groups following $T$. circumcincta infection could be attributed to increased mast cell infiltration in the abomasal mucosa (as observed in these lambs at the same time point; [19]). Increased mast cell infiltration is a characteristic feature of ovine response to nematode infection [63-65]. GATA-3 is reported to be essential in the maintenance of Th2 cytokine production [66]. It is interesting in this context in that the up-regulation of GATA-3, on day 7 , occurred at the same time point as the up-regulation of Th2 related cytokine genes.

The lack of a significant difference in some of the interleukins, such as IL-4, could be due to the tissue sampled rather than differential expression between the lambs. T cell - dendritic cell (DC) interactions in the lymph node is a key step in T cell priming [67]. Since most pathogens, including nematodes, enter the body through non-lymphoid tissue, tissue resident DCs depend on pathogen derived signals to mature and migrate to the local lymph nodes, where they present antigens to naïve $\mathrm{T}$ cells [68]. Additionally, $\mathrm{T}$ cell 
activation is dependent on eliciting an intracellular signal which is strong enough to irreversibly commit the cell to differentiate [69]. Consequently, the mucosa not being the recognised site of $\mathrm{T}$ cell-DC interactions may result in weak signals hence less $\mathrm{T}$ cell activation. Analyses of the abomasal lymph node may provide a better snap shot of the $\mathrm{T}$ cell specific immune response than the abomasal mucosae. However, the lymph node being the main site of $\mathrm{T}$ - dendritic cells interactions may skew the observed expression of cytokines since this will represent expressions induced by all pathogens resident in the host at the time of sampling. It is noteworthy that, except for a few cytokines, results obtained from independent assays done on lymph nodes draining the abomasal mucosa $[12,18]$ or the abomasal mucosa [13] are comparable.

In general, effector immune molecules will not be immediately available following invasion by a novel pathogen [70]. A time delay between infection and immune initiation and a gradual build-up in immune efficacy is expected to occur following infection [71]. Therefore the sampling time can significantly influence the immune factors observed in infected animals. From the current study, it appears that the DRB1*1101 carrier lambs had a shorter time delay relative to the noncarrier lambs. By day 3, DRB $1 * 1101$ carrier lambs were clearly expressing pro-inflammatory cytokines IL-1 $\beta$ and IFN $\gamma$, whereas similar observations were not made until day 7 in the non-carriers. Interestingly, by $35 \mathrm{dpi}$, the cytokine levels in both genetic groups had returned to pre-infection levels. This can partly be attributed to down regulation of the cytokine production to limit the energy cost associated with a strong immune response $[38,39]$. Even though the cytokine environment is considered the key factor in determining naïve $\mathrm{T}$ cell differentiation [72,73], other factors including antigen dose, ligand alterations and antigen presenting cells can influence naïve $\mathrm{T}$ cell differentiation [74]. Consequently, the expression of MHC-II molecules on the APC may play an important role in initiating a faster $\mathrm{T}$ cell response. However, how the MHC-II alleles can lead to the faster immune response in resistant compared to the susceptible lambs in the current study is not clear since it has been reported that there seems to be no differences in antigen recognition amongst the various $\mathrm{MHC}$-II alleles [75]. Nevertheless, a faster immune response has also been reported in resistant lambs compared to susceptible lambs infected with gastrointestinal nematodes $[11,76]$. Since there is a shorter time to respond to the infective larvae before it moves to abomasal mucosa (day 3 to 7, Barbara G, personal communication), it would appear that a faster $\mathrm{T}$ cell immune response in the carrier lambs, enables these lambs to control the parasite burden by reducing the number of larvae that do eventually develop into adults. It is indicative that a key feature of nematode resistance is the inhibition of larval development at the tissue-residing L4 stage $[77,78]$. A similar switch from a Th1 to a Th2 and Tregulatory immune response has also been observed in schistosomiasis $[79,80]$. A possible explanation for the lack of a clear Th1/Th2 phenotype in sheep is the expression of immunoregulatory genes. From these results, it can be concluded that variation in resistance to gastrointestinal nematodes is due to differential interplay in the expression of genes involved in Th1, Th2, and immunoregulatory responses.

\section{Acknowledgements}

The authors wish to thank Dr Marion Ryan for assistance with the gene expression data normalisation and analysis. We also wish to thank the technical staff at Teagasc Animal Research Centre, Athenry and Lyons Research Farm taking care of the animals. MH was sponsored by a Teagasc Walsh fellowship.

\section{Author details}

${ }^{1}$ School of Agriculture, Food Science, and Veterinary Medicine, University College Dublin, Dublin 4, Dublin, Ireland. ${ }^{2}$ Teagasc Animal Production Research Centre, Athenry, Co. Galway, Ireland.

\section{Authors' contributions}

JP, TS and GM conceived of the study. MH, JP, TS, and BG designed the experiments. $\mathrm{BG}$ and $\mathrm{MH}$ collected samples. $\mathrm{MH}$ carried out the experiments and drafted the manuscript. All the authors have read and approved the manuscript.

\section{Competing interests}

The authors declare that they have no competing interests.

Received: 4 June 2010 Accepted: 25 January 2011

Published: 8 March 2011

\section{References}

1. Miller JE, Horohov DW: Immunological aspects of nematode parasite control in sheep. J Anim Sci 2006, 84(E):E124-E132.

2. McLeod RS: Cost of major parasites to the Australian livestock industries. Int J Parasitol 1995, 25:1363-1367.

3. Nieuwhof GJ, Bishop SC: Costs of major endemic diseases of sheep in Great Britain and the potential benefits of reduction in disease impact. Anim Sci 2005, 81:23-29.

4. Jackson F, Coop RL: The development of anthelmitic resistance in sheep nematodes. Parasitol 2000, 120(Suppl):S95-S107.

5. Waller PJ: Nematode parasite control of livestock in the tropics/ subtropics: the need for novel approaches. Int J Parasitol 1997, 27:1193-1201.

6. Papadopoulos E: Anthelmintic resistance in sheep nematodes. Small Ruminant Res 2008, 76(1-2):99-103.

7. Coles GC: Anthelmintic resistance - looking to the future: a UK perspective. Res Vet Sci 2005, 78(2):99-108.

8. Gill HS: Cell-mediated immunity in Merino lambs with genetic resistance to Haemonchus contortus. Int J Parasitol 1994, 24:749.

9. Gill HS, Altmann K, Cross ML, Husband AJ: Induction of T-helper 1- and Thelper 2-type immune responses during Haemonchus contortus infection in sheep. Immunobiol 2000, 99:458-463.

10. Balic A, Bowles VM, Meeusen ENT: Mechanisms of immunity to Haemonchus contortus infection in sheep. Parasite Immunol 2002, 24:39-46.

11. Lacroux C, Nguyen TH, Andreoletti O, Prevot F, Grisez C, Bergeaud JP, Gruner L, Brunel JC, Francois D, Dorchies P, et al: Haemonchus contortus (Nematoda: Trichostrongylidae) infection in lambs elicits an unequivocal Th2 immune response. Vet Res 2006, 37:607-622. 
12. Craig NM, Miller HRP, Smith WD, Knight PA: Cytokine expression in naive and previously infected lambs after challenge with Teladorsagia circumcincta. Vet Pasitol 2007, 120:47-54

13. Ingham A, Antonio R, Ross W, Hunt P, Moira M: Gastrointestinal nematode challenge induces some conserved gene expression changes in the gut mucosa of genetically resistant sheep. Int J Parasitol 2008, 38(3-4):431-442.

14. Shakya KP, Miller JE, Horohov DW: A Th2 type of immune response is associated with increased resistance to Haemonchus contortus in naturally infected Gulf Coast Native lambs. Vet Parasitol 2009, 163(12):57-66

15. Pernthaner A, Cole S, Morrison L, Hein W: Increased expression of interleukin-5 (IL-5), IL-13, and tumor necrosis factor alpha genes in intestinal lymph cells of sheep selected for enhanced resistance to nematodes during infection with Trichostrongylus colubriformis. Infect Immun 2005, 74(4):2175-2183.

16. Keane O, Zadissa A, Wilson T, Hyndman D, Greer G, Baird D, McCulloch A, Crawford A, McEwan J: Gene expression profiling of Naive sheep genetically resistant and susceptible to gastrointestinal nematodes. BMC Genomics 2006, 7(1):42

17. McNeilly TN, Devaney E, Mathews JB: Teladorsagia circumcincta in sheep abomasum: defining the role of dendritic cells in T cell regulated and protective immunity. Parasite Immunol 2009, 31:347-356.

18. Halliday AM, MCAllister HC, Smith WD: Kinetics of the local immune response in the gastric lymph of lambs after primary and challenge infection with Teladorsagia circumcincta. Parasite Immunol 2010 32(2):81-90.

19. Hassan M, Barbara G, Hanrahan JP, Campion D, Sayers G, Mulcahy G, Sweeney $T$ : The dynamic influence of the $D R B 1 * 1101$ allele on the resistance of sheep to experimental Teladorsagia circumcincta infection. Vet Res

20. Schwaiger FW, Gostomski D, Stear MJ, Duncan JL, McKellar QA, Epplen JT, Buitkamp J: An ovine major histocompatibility complex DRB1 allele is associated with low faecal egg counts following natural, predominantly Ostertagia circumcincta infection. Int J Parasitol 1995, 25:815-822.

21. Stear MJ, Bairden K, Bishop SC, Buitkamp J, Epplen JT, Gostomski D, Mckellar A, Schwaiger FW, Wallace DS: An ovine lymphocyte antigen is associated with reduced faecal egg counts in four-month-old lambs following natural, predominantly Ostertagia circumcincta infection. Int J Parasitol 1996, 26:423-428.

22. Sayers G, Good B, Hanrahan JP, Ryan M, Angles JM, Sweeney T: Major histocompatibility complex DRB1 gene: its role in nematode resistance in Suffolk and Texel sheep breeds. Parasitol 2005, 131:403-409.

23. The Immuno Polymorphism Database. [http://www.ebi.ac.uk/ipd/mhc/ index.html].

24. Schwaiger FW, Epplen JT: Exonic MHC-DRB polymorphisms and intronic simple repeat sequences: Janus' faces of DNA sequence evolution. Immunol Rev 1995, 143:199-224.

25. Pfaffl MW: Quantification strategies in real-time PCR. In A-Z of quantitative $P C R$. Edited by: Bustin SA. La Jolla, CA, USA: International University Line (IUL); 2004:87-112

26. French AT, Knight PA, Smith WD, Brown JK, Craig NM, Pate JA, Miller HRP Pemberton AD: Up-regulation of intelectin in sheep after infection with Teladorsagia circumcincta. Int J Parasitol 2008, 38(3-4):467-475.

27. Vandesompele J, De Preter K, Pattyn F, Poppe B, Van Roy N, De Paepe A, Speleman F: Accurate normalization of real-time quantitative RT-PCR data by geometric averaging of multiple internal control genes. Genome Biol 2002, 3(7):1-11.

28. Bonhoeffer $S$, Nowak MA: Mutation and the evolution of virulence. Proc $R$ Soc Lond 1994, B258:133-140

29. Karin SP: Evolution of Pathogen Virulence: The Role of Variation in Host Phenotype. Proc R Soc Lond 2001, B268(1468):755-760.

30. Meeusen EN, Balic A, Bowles V: Cells, cytokines and other molecules associated with rejection of gastrointestinal nematode parasites. Vet Immunol Immunopathol 2005, 108:121-125.

31. Hein WR, Barber T, Cole SA, Morrison L, Pernthaner A: Long-term collection and characterization of afferent lymph from the ovine small intestine. J Immunol Methods 2004, 293:153-168.

32. Claerebout E, Vercauterenm I, Geldhof P, Olbrechts A, Zarlenga DS, Goddeeries BM, Vercruysse J: Cytokine responses in immunised and nonimmunised calves after Ostertagia ostertagi infection. Parasite Immunol 2005, 27:325-331.
33. Minton K: Allergy and Asthma: What 'drives' IL-4 versus IL-13 signalling? Nat Rev Immunol 2008, 8(3):166-167.

34. Sayers G, Good B, Hanrahan JP, Mulcahy G, Sweeney T: Breed differences in mucosal and systemic antibody response to nematode infection in sheep: an important role for lgE? Parasitol 2008, 135:71-80.

35. Kooyman FNJ, Van Kooten PJS, Huntley JF, MacKellar A, Cornelissen AWCA Schallig HDFH: Production of a monoclonal antibody specific for ovine immunoglobulin $\mathrm{E}$ and its application to monitor serum $\lg \mathrm{E}$ responses to Haemonchus contortus infection. Parasitol 1997, 114(04):395-406.

36. Sakaguchi S, Yamaguchi T, Nomura T, Ono M: Regulatory T cells and immune tolerance. Cell 2008, 133(3):775-787.

37. Yamaguchi K, Sakaguchi S: Peripheral tolerance to allergen mediated by regulatory T cells. Nippon Rinsho 2009, 64(11):2063-2070.

38. Colditz IG: Six costs of immunity to gastrointestinal nematode infections. Parasite Immunol 2008, 30(2):63-70.

39. Greer AW: Trade-offs and benefits: implifications of promoting a strong immunity to gastrointestinal parasites in sheep. Parasite Immunol 2008, 30:123-132.

40. Sykes AR: Manipulating host immunity to improve nematode parasite control -Quo vadit. Parasite Immunol 2008, 30:71-77.

41. Fontenot D, Gavin MA, Rudensky AY: Foxp3 programs the development and function of $\mathrm{CD}^{+} \mathrm{CD} 25^{+}$regulatory T cells. Nat Immunol 2003, 4(4):330-336

42. Hinks A, Ke X, Barton A, Eyre S, Bowes J, Worthington J, Consortium URAG, Paediatric BS, Group ARS, Thompson SD, et al: Association of the IL2RA/ CD25 gene with juvenile idiopathic arthritis. Arthritis \& Rheumatism 2009, 60(1):251-257.

43. Maizels RM, Yazdanbakhsh M: Immune Regulation by helminth parasites: cellular and molecular mechanisms. Nat Rev Immunol 2003, 3:733-744.

44. Anthony RM, Rutitzky LI, Urban JF, Stadecker MJ, Gause WC: Protective immune mechanisms in helminth infection. Nat Rev Immunol 2007, 7(12):975-987.

45. Gotoh T, Mori M: Arginase II downregulates nitric oxide (NO) production and prevents NO-mediated apoptosis in murine macrophage-derived RAW 264.7 Cells. J Cell Biol 1999, 144(3):427-434.

46. Flaster H, Bernhagen J, Calandra T, Bucala R: The macrophage migration inhibitory factor-glucocorticoid dyad: regulation of inflammation and immunity. Mol Endocrinol 2007, 21:1267-1280.

47. Hudson JD, Shoaibi MA, Maestro R, Carnero A, Hannon GJ, Beach DH: A proinflammatory cytokine inhibits p53 tumor suppressor activity. J Exp Med 1999, 190:1375-1382.

48. Calandra T, Bernhagen J, Mitchell RA, Bucala R: The macrophage is an important and previously unrecognized source of macrophage migration inhibitory factor. J Exp Med 1994, 179:1895-1902.

49. Mitchell RA, Liao H, Chesney J, Fingerle-Rowson G, Baugh J, David J, Bucala R: Macrophage migration inhibitory factor (MIF) sustains macrophage proinflammatory function by inhibiting p53: Regulatory role in the innate immune response. ProcNat Acad Sci USA 2002, 99(1):345-350.

50. Magalhaes ES, Paiva CN, Souza HSP, Pyrrho AS, Mourao-Sa D, Figueiredo RT, Vieira-de-Abreu A, Dutra HS, Silveira MS, Gaspar-Elsas MIC, et al: Macrophage migration inhibitory factor is critical to interleukin-5-driven eosinophilopoiesis and tissue eosinophilia triggered by Schistosoma mansoni infection. FASEB J 2009, 23(4):1262-1271.

51. Stavitsky AB, Metz C, Liu S, Xianli J, Bucala R: Blockade of macrophage migration inhibitory factor (MIF) in Schistosoma japonicum-infected mice results in an increased adult worm burden and reduced fecundity. Parasite Immunol 2003, 25:369-374.

52. Prieto-Lafuente L, Gregory WF, Allen JE, Maizels RM: MIF homologues from a filarial nematode parasite synergize with IL-4 to induce alternative activation of host macrophages. J Leukoc Biol 2009, 85(5):844-854.

53. Cliffe LJ, Potten CS, Booth CE, Grencis RK: An increase in epithelial cell apoptosis is associated with chronic intestinal nematode infection. Infect Immun 2007, 75(4):1556-1564

54. Keane OM, Dodds KG, Crawford AM, McEwan JC: Transcriptional profiling of Ovis aries identifies Ovar-DQA1 allele frequency differences between nematode-resistant and susceptible selection lines. Physiol Genomics 2007, 30(3):253-261.

55. Cook GA, Familari M, Thim L, Giraud AS: The trefoil peptides TFF2 and TFF3 are expressed in rat lymphoid tissues and participate in the immune response. Febs Letters 1999, 456(1):155-159.

56. Hoffmann W, Jagla W, Wiede A: Molecular medicine of TFF-peptides: from gut to brain. Histol Histopathol 2001, 16:319. 
57. Taupin D, Podolsky D: Trefoil factors: initiators of mucosal healing. Na Rev Mol Cell Biol 2003, 4:721-732.

58. Thim L: Trefoil peptides: from structure to function. Cell Mol Life Sci 1997, 53:888.

59. Carine B, Stéphane D, Monique E, Karim B, Markus HH, Nikolaus B, JeanClaude C: IL-4 and IL-13 up-regulate intestinal trefoil factor expression: Requirement for STAT6 and de novo protein synthesis. J Immunol 2004, 172(6):3775-3783.

60. Tsuji S, Uehori J, Matsumoto M, Suzuk iY, Matsuhisa A, Toyoshima K, Seya T: Human intelectin is a novel soluble lectin that recognizes galactofuranose in carbohydrate chains of bacterial cell wall. $J$ Biol Chem 2001, 276:23456-23463.

61. Pemberton A, McAleese SM, Huntley JF, Collie DD, Scudamore CL, McEuen AR, Walls AF, Miller H: CDNA sequence of two sheep mast cell tryptases and the differential expression of tryptase and sheep mast cell proteinase-1 in lung, dermis and gastrointestinal tract. Clin Exp Allergy 2000, 30:818-832.

62. Huntley JF, Newlands GFJ, Jackson F, Miller HRP: The influence of challenge dose, duration of immunity, or steroid treatment on mucosal mast cells and on the distribution of sheep mast cell proteinase in Haemonchus-infected sheep. Parasite Immunol 1995, 14(4):429-440.

63. Seaton DS, Jackson F, Smith WD, Angus KW: Development of immunity to incoming radiolabelled larvae in lambs continuously infected with Ostertagia circumcincta. Res Vet Sci 1989, 46(2):241-246.

64. Stear MJ, Bishop SC, Doligalska M, Duncan JL, Holmes PH, Irvine J, McCririe L, McKellar QA, Sisnki E, Murray M: Regulation of egg production, worm burden, worm length and worm fecundity by host responses in sheep infected with Ostertagia circumcincta. Parasite Immunol 1995, 17:643-652.

65. Miller HRP: Mucosal mast cells and allergic response against nematode parasites. Vet Immunol Immunopathol 1996, 54:331-332.

66. Yamashita M, Ukai-Tadenuma M, Miyamoto T, Sugaya K, Hosokawa H, Hasegawa A, Kimura M, Taniguchi M, DeGregori J, Nakayama T: Essential role of GATA3 for the maintenance of Th2 cytokine production and chromatin remodeling at the Th2 cytokine gene loci. J Biol Chem 2004, M403688200.

67. Jenkins MK, Khorutus A, Ingulli E: In vivo activation of antigen-specific CD4 T cells. Ann Rev Immunol 2001, 19:23-45.

68. Hommel M: On the dynamics of T-cell activation in lymph nodes. Immunol Cell Biol 2004, 82:62-66.

69. Dustin ML, Chan AC: Signalling takes shape in the immune system. Cell 2000, 103:283-294

70. Fenton A, Lello J, Bonsall MB: Pathogen responses to host immunity: the impact of time delays and memory on the evolution of virulence. Proc BiolSci 2006, 273:2083-2090

71. Ahmed R, Gray D: Immunological memory and protective immunity: understanding their relation. Science 1996, 272:54-60.

72. Abbas AK, Murphy KM, Sher A: Functional diversity of helper T lymphocytes. Nature 1996, 383:787-793.

73. O'Garra A: Cytokines induce the development of functionally heterogeneous T helper cell subsets. immunity 1998, 8:275-283.

74. Loke P, MacDonald AS, Allen JE: Antigen-presenting cells recruited by Brugia malayi induce Th2 differentiation of naïve CD4+ T cells. Eur J Immunol 2000, 30:1127-1135.

75. McCririe L, Bairden K, Britton C, Buitkamp J, McKeand JB, Stear MJ: Heterogeneity in the recognition of Ostertagia circumcincta antigens by serum antibody from mature, infected sheep. Parasite Immunol 1997, 19:235-242.

76. Balic A, Cunningham CP, Meeusen EN: Eosinophil interactions with Haemonchus contortus larvae in the ovine gastrointestinal tract. Parasite Immunol 2006, 28:107-115.

77. Halliday AM, Rouledge CM, Smith SK, Mathews JB, Smith WD: Parasite loss and inhibited development of Teladorsagia circumcincta in relation to the kinetics of local IgA response in sheep. Parasite Immunol 2007, 29:425-434.

78. Smith W, Jackson F, Jackson E, Williams J, HR M: Manifestations of resistance to ovine ostertagiasis associated with immunological responses in the gastric lymph. $J$ Comp Pathol 1984, 94(4):591-601.

79. La Flamme BC, MacDonald AS, Pearce EJ: Role of IL-6 in directing the initial immune response to Schistosome eggs. J Immunol 2000, 164:2419-2426.
80. Vella A, Pearce EJ: CD4+ Th2 response induced by Schistosoma mansoni eggs develops rapidly, through an early, transient, Th0-like stage. $J$ Immunol 1992, 148(7):2283-2290.

doi:10.1186/1297-9716-42-45

Cite this article as: Hassan et al: A differential interplay between the expression of Th1/Th2/Treg related cytokine genes in Teladorsagia circumcincta infected DRB1*1101 carrier lambs. Veterinary Research 2011 42:45.

\section{Submit your next manuscript to BioMed Central and take full advantage of:}

- Convenient online submission

- Thorough peer review

- No space constraints or color figure charges

- Immediate publication on acceptance

- Inclusion in PubMed, CAS, Scopus and Google Scholar

- Research which is freely available for redistribution

Submit your manuscript at www.biomedcentral.com/submit
Ciomed Central 